\begin{tabular}{|ccc|}
\hline & Uniqbu Journal of Social Sciences (UJSS) & \\
\hline Volume 1 & Nomor 3, Desember 2020 & Halaman 38-46 \\
\hline
\end{tabular}

\title{
ANALYSIS COMMON MISTAKES OF WRITING ABSTRACT TRANSLATION ON NURSING STUDENTS AT MOLUCCAS CHRISTIAN UNIVERSITY OF INDONESIA
}

\author{
(Analisa Kesalahan Umum dalam Translasi Penulisan Abstrak Mahasiswa Keperawatan) \\ Debora Harsono \\ Fakultas Kesehatan, Universitas Kristen Indonesia Maluku \\ deboraharsono15@gmail.com
}

(Diterima: 01 Desember; Direvisi: 05 Desember; Disetujui: 08 Desember 2020)

\begin{abstract}
This paper presents a tend to explain about the Analysis Common mistakes of writing Abstract Translation. As matter of fact, we realize that many students likes to translate their abstract by helping Google Translation, it includes the nursing students at UKIM has the habitual action to translate their Abstract by helping Goggle Translation. This research method uses an analysis. To achieve the credibility of data for this research, the researcher uses the data of Abstract Translation from nursing students on their mini thesis / skripsi. Finally, through this paper we can prove that we can find many common mistakes of writing Abstract Translation on Nursing students at Moluccas Christian University of Indonesia. Shortly, we can conclude that the nursing students of UKIM choose to translate Abstract Translation by Google Translate, and finally we need an expert to check all the common mistakes of writing Abstract translation.

Keywords: Mistake analysis, abstrak, writing, translation
\end{abstract}

\begin{abstract}
Abstrak
Makalah ini membahas tentang Analisis Kesalahan Umum dalam Penulisan Abstrak Terjemahan. Faktanya, kami menyadari bahwa banyak mahasiswa yang suka menerjemahkan abstrak mereka dengan membantu Google Translation, termasuk mahasiswa perawat di UKIM memiliki kebiasaan untuk menerjemahkan Abstrak mereka dengan membantu Goggle Translation. Metode penelitian ini menggunakan analisis. Untuk mencapai kredibilitas data penelitian ini, peneliti menggunakan data Abstrak Terjemahan dari mahasiswa keperawatan pada skripsi / tesis mereka. Akhirnya melalui makalah ini dapat dibuktikan bahwa banyak kesalahan umum yang ditemukan dalam penulisan Abstrak Terjemahan pada mahasiswa Keperawatan Universitas Kristen Maluku Indonesia. Secara singkat dapat disimpulkan bahwa mahasiswa keperawatan UKIM memilih untuk menerjemahkan Terjemahan Abstrak dengan Google Translate, dan terakhir dibutuhkan seorang ahli untuk memeriksa semua kesalahan umum dalam penulisan Terjemahan Abstrak.

Kata Kunci: Analisa kesalahan, penulisan, abstrak, terjemahan
\end{abstract}

\section{INTRODUCTION}

Finishing the study is the final goal of someone's life that needs to conduct on their long time studying process. When the students are on the forth grade of their study, they are really need to be seriously to finish their study time by doing the mini thesis persistently.
Doing mini thesis / skripsi is a duty for them. It is the final prerequisite to be needed as a demand from the University. It includes the academic systems process that has establishment by the Education Department of Indonesia formally.

Mini thesis is the form of analytic thinking that need as the proof of their depths knowledge. If they conduct it very 
well, it means they are suitable be called as the bachelor. Shortly, they can include to be graduated on the graduation ceremony.

Mini thesis is the final step of an Educational System at the First Strata (Under Graduate Level) / S1 grade. It must be realized in the form of writing a scientific paper. The description of this mini thesis is summarized on a piece paper of Abstract writing and usually is placed at the front of the thesis after the Table of Contents. For the sake of the academic world that is quite dynamic. In fact, Abstract writing must be translated into Foreign Languages, namely English. Actually, it must be translated into two languages, English and Indonesia language.

This digital era shows about the easiness and speedity in many aspects, include on the Education System. So the students have a tend to use the Google's translation to help them on the process of translating Abstract. In short, this new era the Google system is really covering the importance for rapid and practical Abstract Translation.

As matter of fact, the "helping system" of Google Translate (Google Translation) is very practical and economical side. Practical side because it does not need to find an English expert to translate the contents of the Abstract. It does not need to ask help from some friends, neighbors, or classmates to translate it. Anyway, it will be more practical. Meanly, it does not need a long time process to do it.

It is economical because no adding cost or budget on translation process. Economical for the students it is so important, because they are still depend on their parents to support their life financially. They are really must arrange their budget efficiently. Anyway, it will be more economical. Shortly, it does not need to add their budget to do it.
After being translated by the Google system on translation, the results existence shows many fundamental mistakes. Immediately, the students put the translation on their mini thesis, especially without being examined more closely by the English Lecturer or an English Expert. They always "neglect" about these problems. They are busy enough to prepare themself for the examinations of their mini thesis. Once time, the existence of quality Abstract is gone by the time.

The original translation will be bound together in the form of a mini thesis that has been signed by the supervisors and the examiners. It means, automatically the translation will be recognized or readable by the academic without any validity or correction at all. Anyway, the supervisors and the examiners are concentrated to read and check the content of the mini thesis, finally they always neglect or have no more time to read the Abstract. Shortly, they can be graduated without anymore time to check the contents of Abstract.

In fact, this situation happens years by years without any corrections. Generations by generations were graduated wihout any check on their Abstract writing. This condition will be special concern situations for the English Lecturer specifically and Christian Mollucas Univeristy of Indonesia generally.

\section{THEORITICAL REVIEW}

As supported by many reseachers, translation and interpreting can be perceived as the process that allows the transfer of sense from one language to another, rather than the transfer of the linguistic meaning of each word.

Translation, acoording to Nida (1984) consists in reproducing in the receptor language the closest natural equivalent of the source massage, first in terms of meaning and secondly in terms of style.

Translation theory was once strictly confined within the scope of linguistics for 
translation was merely referred to as a conversion of languages, from the source language into the target language. Nevertheless, when research is carried further and deeper, meaning is found not only associated with the language or the text but also with the author and the reader, which form the tripartite in understanding of the appropriate meaning of any text.

As a note : Hermeneutics is quite relevant with the translation. Because there is no translation without understanding and interpreting texts, which is the initial step in any kinds of translation of course. Inapproriate interpretation inevitably results in adequate translations, if not absolutely wrong translations.

Furthermore, after we discuss about the theories of translation, I would like to discuss and explain about many errors that usually occur in writing an Abstract Translation. Indeed, there are still many others fatal errors that have not been found. The following are the mistakes that usually occur and are mostly done by Nursing Students in writing an Abstract Translations.

Herewith the description of the mistake :

I. The Composition of Sentences consisting of SPOK

SPOK ( Subyek, Predikat, Obyek, dan

Keterangan) in Indonesia language explanations.

OK (Subject, Predicate, Object and Description / Explanation) are often ignored on writing Abstract Translation. They write sentences without including the subject and the explanation of time at the beginning of the sentence, there is no an object, and without the explanation of manners in the end of the sentences. Using of verbs does not included, sometimes verbs are written but overlapping functions with the use of to be.

\section{RESEARCH METHOD}

This research is a research qualitative descriptive. Descriptive research qualitative is a research method based on the philosophy of postpositivism, used to examine the object's condition patterns which is natural where the researcher is key instruments, data collection techniques performed in a tringulation (combined), data analysis is inductive (qualitative) and Qualitative research results emphasize more meaning rather than generalization (Sugiyono, 2014: 9). Things that are described in this research is an abstract writing error. The variable used in This research is a single variable that is abstract writing errors. Error referred to in this research, namely abstract writing errors. Population in this study included all UKIM nursing students. Sample in this study, namely student worksheets.

Researchers used a randomized technique (random sampling) in taking sample data. The data in this study are abstract translations made by students. The instrument used was a test make up. Students are given assignments to create a simple abstract. Researchers have given a few words key as a tool for students to form several sentences. Data in this study analyzed by using the error analysis method stated by Ellis in Tarigan (2011: 60).

\section{DISCUSSION}

Abstract translations of Google's system are mechanical. Because Google's system is kind of the working system that found and settle on the computers. In fact, the translation process carried out by Google is like machine system. When the machine system receives input into Indonesian words, the machine directly translates these words into English.

The machine system only looks for words from Indonesia into English. Then, it can only arrange words by words become one sentences without analysis thinking deeper process anymore. Because 
a machine certainly does not have the ability to consider the rules of the languages / grammar rules (or neglect of its). The machine only knows the words, translate it and done well, finish. No more thinking like human's brain.

In fact, system in a machine only reads and translates rigidly, without any correction or thinking deeper and deeper. Machine is still machine.

The computer system is created / as the results creativity of human, it means the grade ability of computer is under from the human being thinking and analysis (human's brain). Absolutely, the brain of human beings is different with the system working of computers.

Because, the brain of us is created by our God. Meanly, it must be performed the difference working result of these products (between God and human being). This would be one of the weaknesses from Google translation.

The researcher would like to describe wider about the contents of the research. One of the important sides of translation is grammar. Later, we must understand about the definition of grammar.

Grammar : is the rules that say how words change to show different meanings and how they are combined into sentences. Grammar: the set of rules that explain how words are used in a language ; speech or writing judged by how well it follows the rules.

In the field of translation process, we cannot avoid the grammar. The grammar rules have been created and have been legally established / normalized by the Language Institute. Then the grammatical rules must be followed as they are. The grammar rules must be obeyed, do not ignore or violate. Grammar is very important thing on the existence of one's language. Grammar is the basic of language. Without having good grammar we could not speak English well. Anyway, grammar is the heart of language.
The small mistakes that occur on writing transcript of the abstract remain a fundamental error that is quite important, and should not occur and must be considered. We must not assume because these errors are small mistakes and does not important, then it will be underestimated and may be ignored. And many times these errors are neglected. According to the students, they do not need to pay more attention about it. In fact, the Abstract Translation does not check formally at all.

Finally, the process of writing an abstract translation is considered as trivial and does not need to be checked the errors. The Supervisors and the Examiners pay attention that based on the process of the quality contents of a scientific paper so that there is no more time to correct the truth of the abstract translation writing.

Considering the importance of the existence of Abstract Translation on writing mini thesis, that is why the Abstract Translation sheet is placed at the front of mini thesis, after the Table of Contents. That means the presence of Abstract translation is a brief summary of the overall contents of mini thesis. Then, we don't ignore the results of the Abstract translation. Because Abstract Translation has a function as the "advertisement" of the contents of mini thesis.

As we know, the Abstract translation is the "first door" on the process of recognizing the contents of the mini thesis as a whole writing, but it would be one attracting way of the attention from the readers so that they will be more interested in reading and examining on the contents depths of the mini thesis. Interesting or not of its, reviewing the content of the mini thesis must depend on the quality of the Abstract Translation writing process. And the writing of Abstract translation needs to write into two languages, in English and Indonesia languages. It is a formal of requisite of writing Abstract that is 
established by the Education Department of Indonesia.

When the students are using of many words, even they are too long for explaining the meaning of the sentence. When we read the long sentences, automatically the meaning and purpose of the sentence will be blurred / become unclear meaning. It makes the reader become so confused. As matter of fact, Indonesia people and Indonesia students have a tend to use long sentences when they write their paper or mini thesis. They think when they use long sentences, it means the main idea of the pharagraph will be describe clearly. Or it will show the content of the paper will be more qualified. But the opposite one, when we write with long sentences, it will make the main idea become unlear or blur. Many times people do not aware of its condition. It needs special carefulness in writing Abstract Transaltion.

Example 1: The analytic descriptive design used is a cross sectional Study approach. (Google Translation).

Translation : It is used descriptive analytic design with a cross sectional study approach.

Example 2 : What is a study used descriptive analytic design with a cross sectional study approach (Google Translation).

Translation : It is used descriptive analytic design with a cross sectional study approach.

\section{Gerund form (Ing form) as a Subject.}

Gerund is a verb that ending and uses as a noun. Subject does not always begin with the name of the person or subject (I, you, we, they, he, she, it). The subject can be in the form of other forms, namely Gerund as Subject, as an Object, as Complement.

The definition of Gerund is : the verb Ing form of a verb that functions as a noun, ( verb) by adding Ing behind it.
Gerund : the -Ing form of a verb, used like a noun, (for instance, as the subject of a sentence, or after a preposition)

Example 1 : Decrease in blood pressure can be done by consuming banana (Google). Translation : Decreasing in blood pressure can be done by consuming banana.

Example 2 : Drink the guava can decrease the metabolism of the patient's body (Google).

Translation : Drinking the guava can decrease the metabolism of the patient's body.

The word decrease here functions as a Subject. So you must use the Ing Form (Gerund) form at the beginning of a sentence. So the subject in the sentence above does not a subject that refers to the people, but it is a verb that functions as a subject at the beginning of a sentence.

The word drink here functions as a Subject. So you must use the Ing form (Gerund) form at the beginning of a sentence. So the subject in the sentence above does not a subject that refers to the people, but it is a verb that functions as a subject at the beginning of a sentence.

\section{Present - Past Tenses}

Tenses means forms of time. Almost all verbs in English can change form according to the time when they are talking about or when the evident happens. The time signal is important part of English Tenses. The use of Present Tenses --- Past forms in writing Abstract is mixed and ambiguous. In the whole writing of the Abstract, the Tenses Form must be settled (steady) and appropriate. Because the writing of the mini thesis is scientific then it uses the Present form from the beginning up to the end of the Abstract contents.

Even though the students had done the research in the past time / it has already passed (Past Tense). But the topic which they write becomes a scientific fact of truth, and the facts about that truth have 
been tested. Then the Form of Tenses uses the Present Tense Form.

We can find in writing Abstract, at the beginning of a paragraph written in Present Form. But at the end of a paragraph it was written in Past Form. Then there is inconsistency of the confusing Tenses.

Example of Present 1 : This study aimed to determine the relationship nurse's knowledge and attitudes with nurse's skills in minimizing anxiety due to hospitalization of children at RSUD dr. M. Haulussy Ambon.

Translation : This study aims to determine the relationship of nurses knowledge and attitudes with nurses skills in minimizing anxiety due to hospitalization of children at RSUD dr. M. Haulussy, Ambon.

Example of Present 2 : This research is doing well at RST Ambon during two months

Translation: This research have done well at RST Ambon during two months.

Example of Past 1 : The design_used this study was a descriptive analytic survey using a cross sectional approach.

Translation : The design that was used this study was a descriptive analytic survey using a cross sectional approach.

Example of Past 2 : The individual approach are not appropriate with the subject of the research.

Translation : The individual approach were not appropriate with the subject of the research.

\section{Phrase}

The use of Phrases of origin or origin combined in a sentence without understanding the meaning. Here with some definitions / meanings of phrase.

The meaning of Phrase :

a. Amir (2010) : A group of words that together have a particular meaning, especially when they express the meaning well in a few words. b. Azar and Hagen (2009) : A phrase is a group of related words that does contain a subject and a verb.

c. Barnhart (1982) : A phrase is a group of words not containing a subject and a verb and used as a single word with a sentence.

d. Glenn Leggest (1985) : A phrase is a group of related words that has no subject /predicate and is related as a single part of speech.

e. Kay Sayce (2007) : A phrase is a group of grammatically related words that does not include a subject linked to a verb.

f. Ruggiero (1981) : sekelompok kata yang membentuk bagian yang berbeda dari kalimat, tetapi tidak mengandung subyek / predikat.

The term English in the term has a special meaning. In English writing you should not use any words in accordance with the translation. But must use the Phrase Form. Because each phrase has its own meaning or different meanings.

Example 1 : Elderly is part of the process of growth and development (Goggle).

Translation : Become older is part of the process of growth and development.

Example 2: This research is done on Ina Kaka the Old House of Ambon. (Google).

Translation : This research is done on Ina Kaka Decrepit House of Ambon.

Example 3 : The elderly people stay in the Ina Kaka (Google).

Translation: The old people stay in Ina Kaka Decrepit House.

\section{Use of Preposition}

The definition of Preposition : a word like on, off, of, into, normally followed by a noun or pronoun. The other definition of Preposition : a word governing, and ususally preceding, a noun, or pronoun and expressing a relation to another word or element in the clause. 
The use of prepositions may not be written origin / install origin using Google Translations. But the use of prepositions must be in accordance with the rules of grammar that are correct and valid.

The Preposition is a preposition associated with other words to make its own meaning. The Placement of Preposition must pay attention with the type of words that accompany it. Preposition is small part of structure / grammar, but we could not neglect of it.

Example 1: Relationship to anxiety and sleep quality with the length Hemodialysis to patients with chronic kidney failure in RSUD dr. M. Haulussy Ambon (Google Translation)

Right : The relationship between anxiety and sleep quality with the length of Hemodialysis in patients with chronic kidney failure at RSUD dr. M.Haulussy Ambon.

Example 2 : Length relationship treatment Schizophrenia patient with the family stress at RSUD Haulussy Ambon.

Right : The length of relationship treatment Schizophrenia patient with the family stress at RSUD Haulussy Ambon.

The Facts prove that the Google Translation System does not possible to think and analyze whether the preposition is appropriate / not yet in use (appropriate preposition). The systems only reads and transtlate whatever words that they can "catch" without thinking anymore which preposition that suitbale to use on that sentences.

\section{Comparatives}

Comparatives are levels of comparison formed from adjective that mean more than adjectives themselves. Comparison of Adjective needs to be studied to show the level of Adjective Comparison especially related to Adjective of quality and numerals (numbers).

The Comparative recognizes three levels :
First, a Positive Degree is comparable / equivalent / peer. Two sentences of equal status.

Second, Comparative Degree (more level). The first sentence has more meaning than the meaning of the second sentence.

Third, the Superlative Degree (highest level) is an adjective that has the highest or lowest level / degree compared to the others.

Example 1 : The more obedient of the patients, they are easy to drink some medicine and do some treatment. (Google)

Translate : The more obedient of the patients, the easier of them to drink some medicine and doing some treatment.

Example 2: The more clever of their children, they drink many vitamins to cover their need.(Google).

Translate : The cleverest of their children, the more vitamins of them to cover their need.

VII. Writing date and time

The research happens according with the time and date. Time and date are related enough with the events of the research. And the date, time of data must be written with the Formal English.

\subsection{Writing date}

Writing date firstly must start with the name of month, then the numbers of day, and finally the numbers of years. These sequences could not be changed.

Example 1: The research happens on 20 January until 20 March 2018 (Google).

Translation: The research happens on January 20 up to March 202018.

\subsection{Writing time}

Writing about the time needs to tell minutes first then the hours.

It could not write it by up side down.

Example 1: The patient needs to drink the medicine at ten past twenty / pk. 10.20 (Google). 
Translation : The patient needs to drink the medicine at twenty past Ten / pk. 10.20 .

Example 2: The patient has registered at the hospital at ten hours. (Google)

Translation : The patietns has registered at the hospital at ten o'clock.

Mistakes is still mistakes. We could not "erase" it at once time. Erasing does not an easy one. We must " erase" by thinking and analyse it in detail. An English lecturer must correct it very well. All of the students must aware about this problem. They must understand about the importance of good writing in Abstract Translation. All of the Faculty should in "one voice" to decrease the quality of writing Abstract Translation of mini thesis specifically and Mollucas Christian Univeristy oof Indonesia generally.

Certainly, we can not ignore it anymore. Finally, the researcher had described vividly about some of the minor mistakes that are important, fundamental and often occur in writing Abstract Translations of Nursing Students at the Moluccas Christian University of Indonesia. Because of time limitness, the researcher can only describe some of the Abstract Translation Mistakes.

Indeed, in fact there are still many other mistakes that have not occurred or have not been found by the author.

\section{CLOSING}

Therefore, we must be more vigilant and careful in responding to the occurrence of errors in writing abstracts. This alert attitude must also be

\section{REFERENCES}

Amri, M., Afifuddin, A., \& Bin-Tahir, S. Z. (2018). Religious Pluralism of the Indonesian Traditional Islamic Education Institutions. The Journal of Social Sciences Research,4(12), 446450 . "transmitted" to the other faculties at one's University.

It is recommended that every English lecturer plays a role in editing / checking mistakes that often occur in writing Abstract.

So that, all of English lecturers need to be involved to check the abstract translation. And the mistakes will be avoided or reduce the frequency of errors. Actually, UKIM needs to recruit some new English Lecturers to correct the errors on writing the Abstract Translation process of many Faculties of UKIM. Automatically, a new system will be created in which all thesis files must be edited or corrected by English Lecturers in every Faculty.

In fact, on this digital era, all of thesis files from the students can be read by everyone in everywhere. If it does not to be edited, then all the forms of errors will be read, known and even ridiculed by other students from the other campus, even by the society.

All of these things will eventually become something that embarrasses the University generally and the Faculty in particularly. Finally, this simple writing can be an important input for the development of the quality of the human resources of students generally, as well as for the lecturers in particularly.

Amri, M., Tahir, S. Z. A. B., \& Ahmad, S. (2017). The Implementation of Islamic Teaching in Multiculturalism Society: A Case Study at Pesantren Schools in Indonesia. Asian Social Science, 13(6), 125. 
Amri, M., Mosiba, R., \& Bin-Tahir, S. Z. (2020). Interreligious Tolerance in the Perception of Maluku Muslim Society. Jurnal Adabiyah, 20(1), 178-195.

Bin-Tahir, S. Z., Atmowardoyo, H., Dollah, S., \& Rinantanti, Y. (2017). Multilingual Instructional Model of Pesantren Schools in Indonesia. Journal of Language Teaching and Research, 8(6), 1210-1216. Byrne, Donn. 1987. Teaching Oral English. Singapore. Longman Singapore Publisher

Bin-Tahir, S. Z., Hanapi, H., Mufidah, N., Rahman, A., \& Tuharea, V. U. Revitalizing The Maluku Local Language In Multilingual Learning Model.

Bin-Tahir, S. Z., Suriaman, A., \& Rinantanti, Y. (2019). Designing English Syllabus for Multilingual Students at Pesantren Schools. Asian EFL Journal, 23(3.3), 527.

Bin-Tahir, S. Z., Atmowardoyo, H., Dollah, S., \& Rinantanti, Y. (2017). Multilingual learning program: pesantren students' perceptions of the multilingual simultaneous-sequential model. JELE (Journal Of English Language and Education), 3(2), 44-53.

Bin-Tahir, S. Z. Avoiding Maluku Local Languages Death Through Embedded Multilingual Learning Model.

Bin-Tahir, S. Z. (2020). The Role of Local Language in Intercultural Communication among Societies of Buru Island.

Bin Tahir, S. Z. (2017). Multilingual teaching and learning at Pesantren Schools in Indonesia. Asian EFL Journal, 89, 7494.

Bin Tahir, S. Z. (2015). Multilingual Education in Pesantren Context. Yogyakarta: Deepublish.

Bin-Tahir, S. Z. (2015). The Power of Love: The Role of Boyfriend in English Language Acquisition.

Bin-Tahir, S. Z., \& Rinantanti, Y. (2016). Multilingual lecturers' competence in english teaching at the university of Iqra
Buru, Indonesia. Asian EFL Journal, 5, 79-92.

Bin-Tahir, S. Z., Suriaman, A., Hanapi, H., Iye, R., \& Umanailo, M. C. B. (2020). Development of Buru Local Language Conversation Material Based on the Communicative-Interactive Approach for Elementary School Students. Solid State Technology, 63(2s).

Bin-Tahir, S. Z. Avoiding Maluku Local Languages Death Through Embedded Multilingual Learning Model.

Bin-Tahir, S. Z., Hanapi, H., Mufidah, N., Rahman, A., \& Tuharea, V. U. Revitalizing The Maluku Local Language In Multilingual Learning Model.

Djuhertati Imam Muhni. 2012. Introduction to Modern English Translation. Yogyakarta. UST Press.

Djunaidi, F. G., Azwan, A. Y. T., Iye, R., \& bin Tahir, S. Z. Decks Range Gola Village Community Begun District Buton District North.

Hewings, Martin .2002. Advanced Grammar in Use, 2nd Edition. Cambridge. England. .

Kartika I. Permata. 2018. Tangkas Mengatasi Kesalahan Kesalahan Umum Bahasa Inggris. Yogyakarta. DIVA Press.

Kay Sauce. 2007. What not to write : A guide to the dos and dont's of good English. Singapore. Talisman Publishing Pte Ltd.

Michael Swan. 1982. Practical English Usage. Oxford. Oxford University Press.

Saidah, U., Bin-Tahir, S. Z., \& Mufidah, N. (2018). ARABIC TEACHERS'COMPETENCE: A CASE OF MADRASAH SCHOOLS IN MALUKU. Ijaz Arabi Journal of Arabic Learning, l(2).

Sukur G, Silvester (2012), Common Mistakes in English Conversations, $1^{\text {st }}$ edition, Yogyakarta, Penerbit Kalarana Press. 
Suryadi, Junaida S. Pd. (2007) Complete English Grammar, 2nd edition, Yogyakarta,Penerbit Pustaka Pelajar.

Supono, Idi (2007), English Grammar, 1 st edition , Jakarta, Penerbit Wahyu Media.

Suriaman, A., Bin-Tahir, S. Z., \& Usman, S. (2019). Designing Web-Based English Listening Instruction: An Analysis of Indonesian University Student's Needs. Asian EFL Journl. Vol. 23 (3.3), 28-40.

Widjaja Grace, Dra. ((2002), Complete English Grammar and The Exercises, $2^{\text {nd }}$ edition, Jakarta, Penerbit PT Bhuana Ilmu Populer.

Yulismayanti, H., Iye, R., \& Susiati, S. Z. B. T. (2020). VARIATIVE METHOD IN IMPROVING STUDENT LEARNING MOTIVATION IN PANDEMIC COVID-19 SITUATIONS. Journal of Critical Reviews, 7(5), 1584-1595.

Bin-Tahir, S. Z. (2015). The Power of Love: The Role of Boyfriend in English Language Acquisition.

Bin-Tahir, S. Z., Amri, M., Nagauleng, A. M., Diniaty, A., \& Hajar, I. (2019). The Social Media Use For Digital Natives: Parenting Model Of Muslim Cleric Families. International Journal of Scientific \& Technology Research, 8(11), 2871-2874.
Bin-Tahir, S. Z., Bugis, R., \& Tasiana, R. (2017). Intercultural Communication of a Multicultural Family in Buru Regency. Lingual: Journal of Language and Culture, 9(2), 8.

Bin-Tahir, S. Z., Saidah, U., Mufidah, N., \& Bugis, R. (2018). The impact of translanguaging approach on teaching Arabic reading in a multilingual classroom. Ijaz Arabi Journal of Arabic Learning, 1(1).

Bin-Tahir, S. Z., \& Rinantanti, Y. (2016). Multilingual lecturers' competence in english teaching at the university of Iqra Buru, Indonesia. Asian EFL Journal, 5, 79-92.

Tahir, S. Z. B., Atmowardoyo, H., \& Dollah, S. (2018). BELAJAR BERBICARA MULTIBAHASA UNTUK SANTRI PESANTREN. Yogyakarta, Deepublish.

Tuharea, V. U., Bin Tahir, S. Z., Ami, I. S. O., \& Rahman, A. (2020). BURU LANGUAGE CONSERVATION THROUGH SUSTAINABLE MULOK LEARNING IN BURU REGENCY: (Konservasi Bahasa Buru melalui Pembelajaran Mulok Berkelanjutan di Kabupaten Buru). Uniqbu Journal of Social Sciences, 1(2), 49-55. https://doi.org/10.47323/ujss.v1i2.30 